\title{
As metamorfoses da quinta musa
}

\author{
Rita Martins
}



José Sasportes, A quinta musa: Imagens da história da dança, Lisboa, Editorial Bizâncio, 2012, 335 pp.

Os ensaios reunidos em A quinta musa: Imagens da história da dança apresentam o percurso de um investigador e uma digressão pela história da dança ocidental. Numa introdução clara e objectiva, José Sasportes justifica a publicação e explica o alinhamento dos dezoito textos,

Rita Martins

é doutoranda em

Estudos de Teatro na Faculdade de Letras da Universidade de Lisboa (FLUL) e investigadora do Centro de Estudos de Teatro da FLUL.

É bolseira da FCT. que seguem uma cronologia da história da dança, embora tenham sido produzidos em diferentes ocasiões - entre 1969 e 2012. Lidos em colóquios e seminários ou dispersos em periódicos, os textos são ordenados com cuidado pedagógico, oferecendo-se um roteiro nítido para o leitor viajar através dos capítulos e das imagens de uma história pesquisada ao longo de anos. E são mais de cinco décadas consagradas à escrita sobre dança. No final de cada ensaio esclarece-se a circunstância da sua elocução ou publicação

e confirma-se, em cada momento da leitura, o entusiasmo de José Sasportes por Terpsicore, a musa da dança.

0 título do primeiro capítulo contém, desde logo, uma declaração de intenções do autor: "A História no centro dos estudos coreológicos" (pp.15-29), reivindicando a dignificação dos estudos de dança sustentada na história. 0 conhecimento histórico é, segundo o autor, o recurso mais seguro para a dança conquistar o seu legítimo espaço na academia e combater, através da investigação rigorosa, a sua dependência em relação às disciplinas da "moda" (como os Estudos Pós-Coloniais ou Feministas) que, muitas das vezes, deturpam a história para servir uma teoria. Consequentemente, o capítulo seguinte - "A Crítica. A História" (pp. 31-39) -,

complementa a reflexão sobre a memória e problematiza a função da crítica de dança a partir de citações, exemplos e atitudes dos críticos face à história que se tece no acto da escrita.

Definido o território teórico, o leitor pode iniciar uma leitura sobre a evolução da dança na Europa, a sua progressiva independência em relação ao espectáculo lírico e a transformação dos paradigmas estéticos ao longo de três séculos. Uma vez que os textos são autónomos, o leitor poderá escolher épocas, geografias, nomes do seu interesse, auxiliado por um precioso Índice Onomástico, ou prosseguir a sequência temporal traçada pelo autor, que destaca a dança em Itália no século XVIII, a passagem para o bailado romântico e o sucesso dos Ballets Russes. Uma sintese destes movimentos pode ser lida em "O Bailado: geometrização, imitação e renascimento de um corpo" (pp. 41-50), um breve ensaio que descreve uma trajectória da dança desde a

Renascença até Pina Bausch, examinando o oscilar entre o figurativo e o abstracto. A história da dança em Itália tem um lugar privilegiado, ocupando quatro textos que demonstram a importância dos coreógrafos e dos bailarinos italianos, contratados pelos teatros de corte e pelos teatros públicos de toda a Europa. As informações são recolhidas em tratados e correspondência de época, peças de Goldoni e libretos, sendo indicadas as edições recentes em notas de rodapé. Em "A palavra contra 0 corpo ou a ópera inimiga do bailado" (pp. 51-74), Sasportes recupera as polémicas teóricas em redor da crescente afirmação do bailado nas óperas, uma presença combatida pelos literatos e solicitada pelo público. 0 bailado pantomima, que tem a tragédia e o dramma per 
musica como modelos, terá uma tradução nos corpos dos bailarinos coreografados por Gaspare Angiolini e JeanGeorges Noverre, criadores de uma poética do gesto narrativo. 0 confronto, e mesmo inimizade, entre os dois coreógrafos e seus discípulos é o assunto principal de "Noverre em Itália" (pp. 95-109), um ensaio que clarifica a recepção dos ballets d'action do coreógrafo francês por ocasião da sua estadia em Milão (1774-1775). Em "A Dança no século XVIII, Veneza por exemplo" (pp. 75-94), Sasportes descreve o fulgor da dança numa cidade onde, nos últimos trinta anos de Setecentos, se dançaram mais de 450 ballets. A digressão setecentista termina com a descrição da actividade do Teatro San Carlo de Nápoles em "Nápoles 1737-1900, um outro exemplo" (pp. 111147), um texto que já indicia a passagem para o século XIX e para o bailado pré-romântico. 0 itinerário por Itália termina, por sua vez, no capítulo "Virtuosismo e espectacularidade, respostas italianas à cadência do bailado romântico" (pp. 149-164).

0 século XX é introduzido com "Danças de pacotilha e exotismos cultos" (pp. 165-183), um texto que se escreve como resposta ao autor de Orientalismo, Edward W. Said e aos teóricos do pós-colonialismo, que vêem no exotismo um prolongamento do gesto imperialista e colonial dos europeus. A argumentação certeira de Sasportes, sustentada na contextualização histórica, conduz às danças audaciosas das mulheres fatais que ocuparam os palcos durante a Belle Époque, cujo mérito e papel na evolução da dança são reconhecidos pelo autor. 0 nascimento dos Ballets Russes, em 1909, é convocado enquanto exemplo de exotismo culto que se desloca de Leste para Oeste, uma viagem e uma história examinadas em "Ballets Russes: Uma guerra, uma revolução, duas vanguardas" (pp. 185210). Fazendo ainda a história da prática coreográfica no século XX, o autor salienta o valor da produção artística de Ida Rubinstein, cuja presença cénica fascinou a intelectualidade parisiense, e em "Expressionismos: sintonias entre as artes visuais e a dança" (pp. 227-241) desloca-se o foco da pesquisa para o clima de intensa criatividade que se vivia na Alemanha e Viena nos anos anteriores à Grande Guerra. Balanchine, Isadora Duncan, Martha Graham, Merce Cunningham são nomes que suscitam uma reflexão apaixonada sobre a dança norteamericana em dois artigos de 1969 e 1971 - altura em que Sasportes fazia crítica de dança - publicados na revista Colóquio/Artes. Os últimos capitulos afastam-se, a nosso ver, do itinerário escolhido, correspondendo à necessidade de uma afirmação política face a acontecimentos recentes: o fim do Ballet Gulbenkian, em 2005, e o anúncio da criação do OPART (Organismo de Produção Artística), em 2006. No final, os textos sobre Pina Bausch são uma justa homenagem à coreógrafa que marcou o autor, o público português que assistiu aos seus espectáculos e a história da dança do século XX.

Os ensaios equilibram a reflexão e a erudição, os dados históricos e a estética numa linguagem dinâmica, reveladora de uma notável capacidade de sintese instrumento poderoso que o autor usa com agilidade na recriação dos contextos históricos, na identificação dos movimentos culturais e na articulação entre nomes e acontecimentos. A revisitação da história da dança sob o ponto de vista do erotismo - "Dança e erotismo: De quem? Para quem?" (pp. 273-297) é um bom exemplo disso. 0 notório domínio da escrita sinaliza, aliás, as várias vocações do historiador, que também se dedica à literatura ficcional e à tradução. 0 espaço dedicado a Itália explicase pelo facto de José Sasportes publicar, desde os anos 80, o resultado das suas investigações neste país, onde, mais recentemente, foi responsável por projectos tão relevantes como: La danza italiana in Europa nel Settecento (Roma, Bulzoni Editore, 2011), Storia della danza italiana dalle origini ai giorni nostri (Torino, EDT, 2011) e La danza italiana in Europa nell'Ottocento (Roma, Aracne Editrice, 2012). José Sasportes é, ainda, indissociável da história da dança em Portugal, já que o investigador colmatou uma lacuna da historiografia portuguesa com a publicação, em 1970, da História da dança em Portugal (Lisboa, Fundação Calouste Gulbenkian). Em 1979 dá continuidade à divulgação da dança no espaço luso com Trajectória da dança em Portugal (Lisboa, Instituto de Cultura e Língua Portuguesa, Biblioteca Breve, série Artes Visuais, n²7) e, por ocasião de Lisboa 94, publica Dançaram em Lisboa 1900-1994, em co-autoria com Maria de Assis e Helena Coelho. Apesar da"escassez de bibliografia portuguesa consagrada à dança" (p. 11), lamentada justificadamente por José Sasportes nas primeiras linhas do livro, é indispensável reconhecer a produção teórica e crítica daqueles que têm, nas últimas décadas, acompanhado a dança em Portugal e lembramos apenas alguns nomes, tais como António Pinto Ribeiro, Daniel Tércio, Maria José Fazenda e Mónica Guerreiro. Hoje, a quinta musa encontrase menos só.
'Podemos encontrar uma sintese deste trabalho em História da dança (comissariado para a Europália 91, Lisboa, Imprensa Nacional Casa da Moeda, 1991), que integra uma importante investigação de António Pinto Ribeiro sobre a dança em Portugal, desde a fundação do Ballet Gulbenkian, em 1965, até ao culminar criativo da Nova Dança portuguesa, em 1990. 